\title{
Multimodal strategy for hand hygiene in field hospitals of COVID-19
}

\author{
Estratégia multimodal para higiene das mãos em hospitais de campanha de COVID-19 \\ Estrategia multimodal para higiene de las manos en hospitales de campaña para COVID-19
}

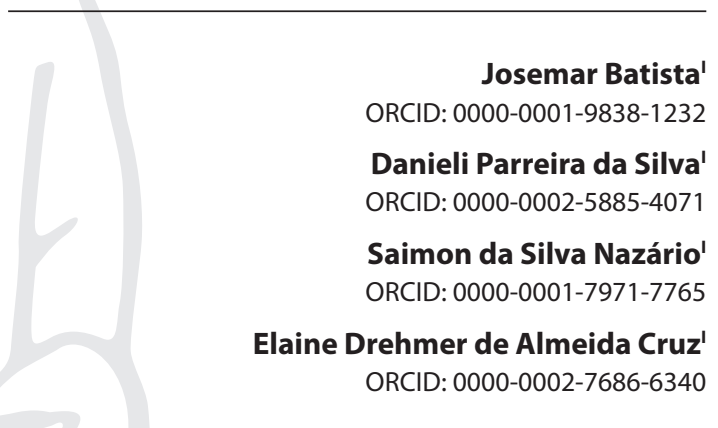

'Universidade Federal do Paraná. Curitiba-Paraná, Brazil.

How to cite this article:

Batista J, Silva DP, Nazário SS, Cruz EDA. Multimodal strategy for hand hygiene in field hospitals of COVID-19. Rev Bras Enferm. 2020;73(Suppl 2):e20200487. doi: http://dx.doi.org/10.1590/0034-7167-2020-0487

Corresponding author: Josemar Batista E-mail: josemar.batista@hotmail.com

EDITOR IN CHIEF: Dulce Barbosa ASSOCIATE EDITOR: Hugo Fernandes

Submission: $05-06-2020$

Approval: 08-22-2020

\section{ABSTRACT}

Objective: Reflect and propose adaptations to the Multimodal Hand Hygiene Strategy for field hospitals, in the context of the COVID-19 pandemic. Method: Reflective study, carried out in April 2020, based on the recommendations of the World Health Organization and the guide for the implementation of the five components of the Multimodal Strategy: system change related to infrastructure; training/education; evaluation and feedback; reminders in the workplace; and institutional security climate. Results: The Multimodal Strategy, proposed for hospitals in general, can be adapted for field hospitals in order to reduce the transmission of the SARS-CoV-2 virus. Investments to adapt the infrastructure and education of workers require foresight and speed and are of special relevance to promote hand hygiene in this care context. Final considerations: Adjusting the Multimodal Strategy, especially for the reduced time in the execution of each component, is necessary for field hospitals with a view to preventing COVID-19.

Descriptors: Hospitals; SARS Virus; Delivery of Health Care; Hand Hygiene; Patient Safety.

\section{RESUMO}

Objetivo: Refletir e propor adaptações na Estratégia Multimodal de higienização das mãos para hospitais de campanha, no contexto da pandemia de COVID-19. Método: Estudo reflexivo, realizado em abril de 2020 com base nas recomendações da Organização Mundial da Saúde e do guia para implementação dos cinco componentes da Estratégia Multimodal: mudança do sistema relacionada à infraestrutura; formação/educação; avaliação e retroalimentação; lembretes no local de trabalho; e clima de segurança institucional. Resultados: A Estratégia Multimodal, proposta para hospitais em geral, pode ser adaptada para hospitais de campanha visando reduzir a transmissão do vírus SARSCoV-2. Investimentos para adequar a infraestrutura e educação de trabalhadores exigem previsão e celeridade e são de especial relevância para promover a higienização das mãos nesse contexto assistencial. Considerações finais: Ajustar a Estratégia Multimodal, em especial para o tempo reduzido na execução de cada componente, é necessário para hospitais de campanha com vistas à prevenção da COVID-19. Descritores: Hospitais; Vírus da SARS; Assistência à Saúde; Higiene das Mãos; Segurança do Paciente.

\section{RESUMEN}

Objetivo: Reflejar y proponer adaptaciones en la Estrategia Multimodal de higienización de manos para hospitales de campaña, para la COVID-19. Método: Estudio reflexivo, realizado en abril de 2020 basado en las recomendaciones de la Organización Mundial de la Salud y guía para implementación de los cinco componentes de la Estrategia Multimodal: cambio del sistema relacionado a la infraestructura; formación/educación; evaluación y retroalimentación; notas en el trabajo; y clima de seguridad institucional. Resultados: La Estrategia Multimodal, propuesta para hospitales en general, podría adaptarse a hospitales de campaña objetivando reducir la transmisión del virus SARS-CoV-2. Inversiones para adecuar la infraestructura y educación de trabajadores exigen previsión y celeridad y son de especial relevancia para promover la higienización de manos en contexto asistencial. Consideraciones finales: Ajustar la Estrategia Multimodal, en especial para el tiempo reducido en la ejecución de cada componente, es necesario para hospitales de campaña con objetivo de prevención de COVID-19.

Descriptores: Hospitales; Virus del SARS; Asistencia a la Salud; Higiene de las Manos; Seguridad del Paciente. 


\section{INTRODUCTION}

The World Health Organization (WHO), faced with problems related to patient safety, encouraged Member States to promote safe care practices, with emphasis on hand hygiene $(\mathrm{HH})$, with the aim of reducing to a minimum acceptable, the Healthcareassociated Infection (HAI). In 2005, this was the topic chosen for the first global challenge for patient safety, and called "Clean care is safer care" ${ }^{\prime \prime(1)}$. In 2009, the campaign "Save Lives: Clean Your Hands" was launched, highlighting the strengthening of "My 5 Moments for Hand Hygiene", and in that same year a guide was made available, for health services, with strategies for implement improvements made to the theme ${ }^{(2)}$.

The guide consists of the Multimodal Strategy for $\mathrm{HH}$, composed of five components: system change related to the infrastructure of the unit/institution; training and education; evaluation and feedback; reminders in the workplace; and institutional security climate. These are covered in five sequential steps: preparing the unit; initial diagnosis; implementation; follow-up assessment; and continuous planning and review cycle ${ }^{(2)}$.

The Strategy has shown promising results in the hospital and out-of-hospital area ${ }^{(3)}$, with emphasis on when all five components of that intervention are used, in an appropriate, articulated and interdependent manner $r^{(4)}$. In addition, the set of actions enables improvements in infrastructure, knowledge and perceptions of health professionals, diagnostic support services and leaders with regard to $\mathrm{HH}$ adherence and practice ${ }^{(5)}$.

Currently, especially in the context of the COVID-19 pandemic, managers, the academic community, health professionals and the population in general recognize the relevance and importance of $\mathrm{HH}$ for personal care and with others. It is, admittedly, conceived as basic and challenging care for patient safety in the face of political, social, educational and geographical differences that impact health services ${ }^{(2,5)}$.

In view of the rapid spread of the Severe Acute Respiratory Syndrome Coronavirus 2 virus (SARS-CoV-2) across continents, the severity of the attack, with emphasis on risk groups, and added to the difficulties in containing the disease, even though basic measures prevention measures can be adopted to mitigate them, the WHO declared it a pandemic in the first quarter of 2020. In this context, efforts are needed to contain COVID-19 cases and reduce lethality ${ }^{(6)}$.

The control of the spread of the virus is based on the triad composed by the universal use of mask, social distance and $\mathrm{HH}$. In this sense, this study aims to discuss $\mathrm{HH}$, one of these factors for patient safety in the face of the COVID-19 pandemic, which consists of a practice strongly related to the knowledge, importance and behavior of the population and health professionals, as well as to the structure available for its timely execution, in view of the current pandemic moment.

Considering the widespread and rapid contagion by the virus, as well as the possibility of saturation of hospitals to deal with cases of medium and high severity ${ }^{(7)}$, there is an urgent need to reorganize health systems with regard to expanding the supply of beds in view of the prospect of growing and immediate demand. From this perspective, adapting spaces for health care takes place progressively in temporary structures built on an emergency basis and in adapted environments, such as hotels, gyms and convention centers ${ }^{(8)}$. These structures constitute the so-called "field hospitals", which have been implemented in several Brazilian states by the State/District/Municipal Health Secretariats ${ }^{(7)}$, like other countries.

Despite being considered a temporary location, it is necessary to define workflows and work routines that provide adequate assistance, including actions to prevent and control infection by the SARS-CoV-2 virus $^{(7)}$. The unprecedented nature of these structures for health care provides special attention with regard to patient safety, requiring observation of the recent recommendations of the Member States to disseminate and promote $\mathrm{HH}$, in the context of the pandemic, in order to minimize the transmission of the virus ${ }^{(9)}$.

Recognizing the importance of ensuring good practices in field hospitals, this theoretical-reflective study has as its theme the applicability of the Multimodal Hand Hygiene Strategy in field hospitals, in the current pandemic scenario.

\section{OBJECTIVE}

Reflect and propose adaptations to the Multimodal Hand Hygiene Strategy for field hospitals, in the context of the COVID-19 pandemic.

\section{DEVELOPMENT}

\section{Multimodal strategy to promote clean and safe care}

From the publication of the first global patient safety challenge to the current recommendations to promote access and practice of $\mathrm{HH}$ in the pandemic by COVID-19(9), WHO Member States recommend guidelines to health units, based on evidence, whose objective is to contribute to these services, in the rise of better structural, process and results indicators ${ }^{(2)}$.

In order to guarantee a continuous and global approach, in the face of a simple action, but at the same time complex from the systemic point of view for its effectiveness, WHO recommends implementing, for the hospital and extra-hospital environment, the Multimodal Strategy. This consists of a set of actions, the objective of which is to reduce the occurrence of preventable infections ${ }^{(2-3)}$, being composed of a series of attributes and steps to be systematized. The key components of the Multimodal Strategy and some of its elements are summarized in Figure 1.

Bearing in mind that field hospitals are managed by already established hospital units, whose operating protocols are extended to this context ${ }^{(10)}$, it is important to adapt the guidelines for an application with time optimization. Conceptually, field hospitals are characterized by provisional units that aim to provide assistance to the patient during adverse situations, such as pandemics, in order to avoid overloading the hospital structure. Thus, even though constituted on an emergency basis, these hospitals must follow the Resolution of the Collegiate Board-RDC n. 50, of February 21, 2002 and other rules of the Health Surveillance, Civil Defense, and the Fire Department ${ }^{(8)}$. Because they are under the management of social organizations or health networks, these structures must guarantee safe patient care, instituting diverse care standards and routines, including those related to patient safety, according to the demand of the assisted population. 


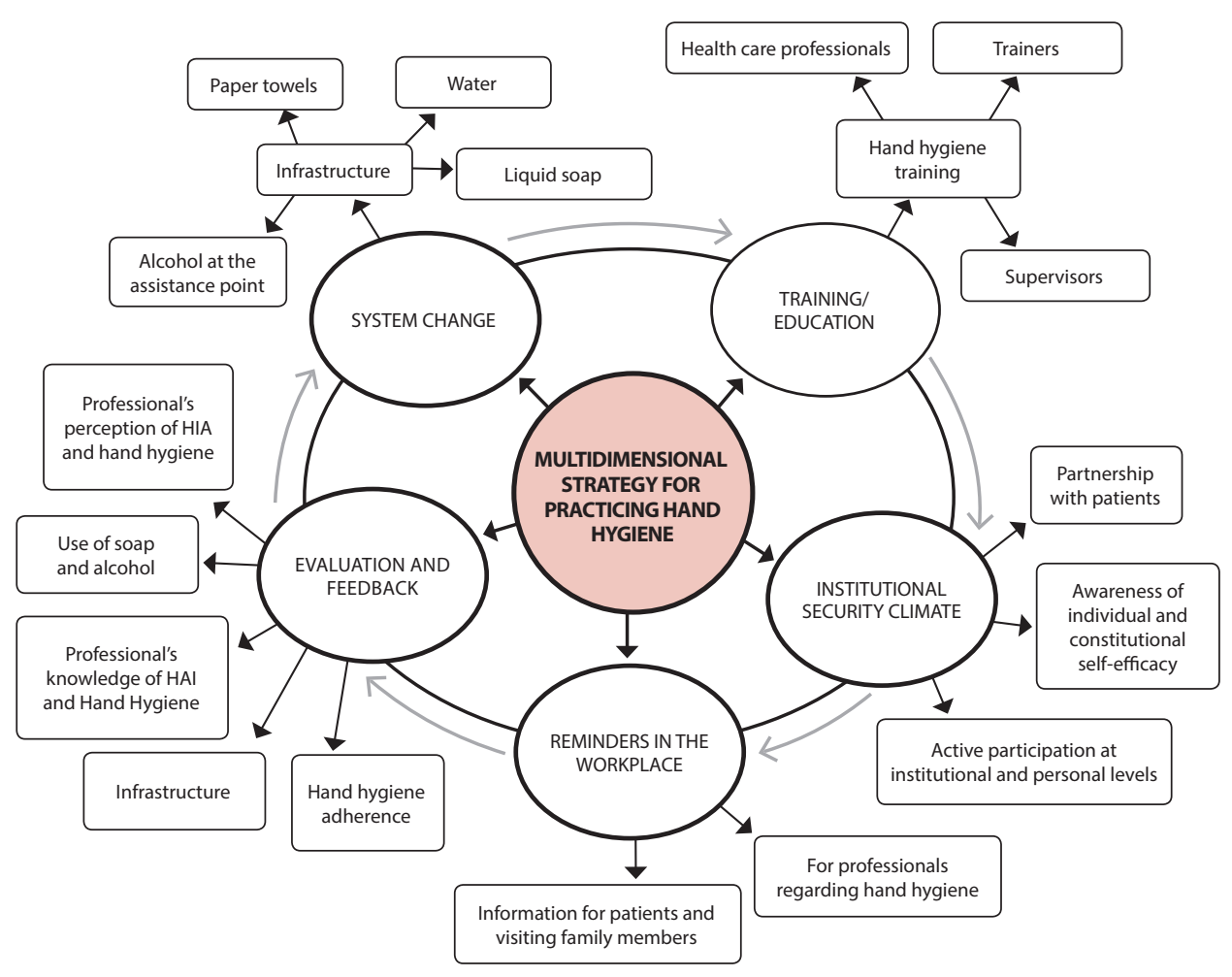

Note: *HAl - healthcare-related infections

Source: Adapted from the World Health Organization, 2009(6)

Figure 1 - Components and elements of the multimodal Strategy for the practice of hand hygiene
Strategy, additional actions are presented in Charts 1, 2 and 3, based on the evidence of the spread of the virus and recommendations in the literature for the control of the pandemic.

Chart 1 shows the component related to infrastructure, with adaptations to the context of a field hospital.

WHO recommends that all health services, public and private, should establish or strengthen their multimodal program and ensure, at a minimum, an adequate amount of materials and update of workers on the theme. These actions are added to educational ones, such as the use of reminders and communications about the importance of $\mathrm{HH}$ in preventing the spread of COVID- $19^{(9)}$.

Thus, taking advantage of different education strategies is useful to fill the gaps about the practice of $\mathrm{HH}$, in the knowledge of professionals about the Mul-
When considering that field hospitals were established to support the hospital network in the pandemic by COVID-19, in view of the evidence of the high transmissibility of the virus, with the hands as a vehicle and temporary source, the adoption of measures that promote $\mathrm{HH}$ constitutes one of the pillars of patient safety. On the other hand, it must be recognized that the managerial model of these structures is not unique ${ }^{(7)}$, which can be one among several reasons why the Multimodal Strategy is not included in the security protocols. It is noteworthy that, in view of the relevant content of this strategy for the improvement and systematization of $\mathrm{HH}$ practices in these assistance points, it is believed that proposing the adoption and adaptations to field hospitals has the potential to make it attractive, in a way that can generate positive results regarding the safety of workers and patients.

Taking into account its five central components (system change related to infrastructure; training and education; evaluation and feedback; reminders in the workplace; and institutional security climate), it is estimated that they should be adjusted for these health assistance points. It is emphasized that changes in the structure, with the availability of human resources and necessary materials in the appropriate places, are important for the care of patients with COVID-19. However, only the presence of inputs does not guarantee a change in the behavior of professionals, with regard to the practice of $\mathrm{HH}^{(4)}$.

Thus, it is necessary and pertinent to recognize that there is a demand for approaches directed to the implementation of the Multimodal Strategy, with regard to the need for adaptations, according to the local reality of the field hospital, so that behavioral changes occur. Based on the fundamental guidelines of the timodal Strategy, as well as about the transmission of the virus and ways of prevention. Chart 2 presents recommendations for the components "Training/Education" and" Reminders to professionals for $\mathrm{HH}$ in the workplace ".

Therefore, it is necessary to recognize limitations that impact the effectiveness of the components presented in Charts 1 and 2. Among them, it follows that, although the measures for $\mathrm{HH}$ are simple and basic, their daily practice is challenging in view of the low adherence of professionals ${ }^{(4)}$, even in traditional health structures. In addition, it is possible to highlight the difficulties of access, or even the lack of inputs, such as alcohol gel(9) and its disposition in the assistance points to prevent the spread of the SARS-CoV-2 virus. Even in such situations, patients and family members should be instructed and encouraged to use alcoholic solutions frequently and in a timely manner. In the current context, fear of the risk of becoming infected with the virus can be an ally to adherence to $\mathrm{HH}$, resulting in an important initiative for self-care. This inference applies equally to patients, companions and family members.

Health education has proven to be effective in raising and maintaining $\mathrm{HH}$ adherence rates, as it allows re-signifying behaviors and assimilating relevant information ${ }^{(4)}$. It is up to the managers of these temporary structures to provide training/ qualifications that aim to contribute to the implementation of a basic $\mathrm{HH}$ program, especially when emergency hiring health professionals, sometimes recently graduated and inexperienced. In the context of the pandemic, the educational component is the key to improving the practice of $\mathrm{HH}$ and becomes influential in the results of the "Evaluation and feedback" component (Chart 3). 
Chart 1 - Component characteristics "Change in the system (infrastructure)" of the Multimodal Strategy and adaptations for the context of field hospitals

\begin{tabular}{l}
\hline Component: "System Change" (Infrastructure) \\
\hline DESCRIPTION \\
It aims to ensure the necessary infrastructure to allow professionals to car- \\
ry out the practice of HH. This component is originally composed of Unit \\
Preparation and Initial Diagnosis. \\
EXPECTED TIME \\
Considering the pandemic situation, this component must occur in parallel \\
with the implantation of the field hospital or, at most, in the first fortnight \\
of operation. In the face of the pandemic, the exclusive preparation is con- \\
sidered to be operational, due to the time limitation prior to the installation \\
of the hospital and through the progressive composition of the team.
\end{tabular}

\section{KEY ACTIONS FOR HH AND PATIENT SAFETY}

- List a key leadership team (nurses and/or doctors) to implement the strategy, including a coordinator and their alternate ${ }^{(2)}$. The patient safety team is composed of the leadership and professionals, being responsible for prevention and infection control actions ${ }^{(7)}$. In a pandemic situation, the leadership needs to use management tools to involve the team in the immediate response to the continuous demands within the provisional structure, as well as, to indicate observers who will act as auditors of adhesion and adequacy of the $\mathrm{HH}$ practice.

- Make supplies available, such as drinking water, liquid soap, paper towels and alcoholic solution, at the service/assistance point, in circulation corridors, at entrances and other environments, in sufficient quantity ${ }^{(2,8)}$. The availability of alcoholic solution close to the point of assistance provides opportunities for its use, before and after touching the patient or the care environment, reducing the risk of carrying the virus.

- Consider pocket flasks containing alcoholic preparations for health and support professionals ${ }^{(2)}$, a fundamental strategy in preventing virus transmission.

- Install washbasins with sufficient size and depth for washing hands and forearms, observing the sink/patient's bed ratio of at, least 1:10 ${ }^{(2)}$. If there are no other possibilities, portable washbasins can be used in field hospitals, as long as strict water supply and sewage processes are established ${ }^{(10)}$. This recommendation is fundamental, considering structures adapted for health care.

The institutional security climate is crucial to review the cycles related to the previous steps, and its purpose is to create an environment and perceptions that facilitate awareness of health security issues. In this way, adhesion, opportunity and quality in $\mathrm{HH}$ are ensured; and the theme and improvements are considered a high priority issue at all hierarchical levels of the unit ${ }^{(2)}$. It should be noted that the actions developed in this component are important for behavioral changes to occur and result in safe care. Achieving continuous improvements in patient safety, with the application of the Multimodal Strategy, depends on the understanding of the actors involved in the care ${ }^{(2)}$, especially when considering the field hospital environment, aimed at patients with COVID-19 and, therefore, possible source for spreading the virus. It is worth remembering that the workers themselves can constitute a source of the virus, reiterating the importance of appropriate behavior, including respiratory etiquette, universal use of a mask and $\mathrm{HH}$.

The feedback of the indicators to those involved in the care, including the active participation of patients and family members, favors the positive construction of the safety climate $^{(4)}$, essential to promote clean and safe care. In this unprecedented moment, it is important not to overload those involved with negative criticism, but rather to highlight the progress made and those points that can still be improved. In view of the identified gaps, feedback should emphasize $\mathrm{HH}$ as a self-protection practice, encouraging adherence as a strategy to prevent the spread of this viral disease.
Chart 2 - Characteristics of the "Training / Education" and "Reminders in the Workplace" components of the Multimodal Strategy and adaptations of the recommendations for the context of field hospitals

\section{Component: “Training/Education"}

\section{DESCRIPTION}

Vital component that integrates strongly with the other components and induces behavioral and cultural changes through adequate theoretical and practical training ${ }^{(2-3)}$.

EXPECTED TIME

This component must be conducted previously at the start of activities at the field hospital, as well as in parallel, during activities, considering the high transmissibility of SARS-CoV-2. Educational activities should occur continuously whenever new professionals are hired or, also, if there is low effectiveness of previous educational interventions, measured by audits or evidenced by horizontal virus transmission indicators between patients and workers, who are part of another item of the multimodal structure, which for now will not be discussed in this study.

\section{KEY ACTIONS FOR HH AND PATIENT SAFETY}

- Establish requirements for basic education for trainers, observers and health professionals. For example, workers' lack of knowledge about policies, standards, protocols, standard operating procedures directed to $\mathrm{HH}^{(2)}$, especially those related to COVID-19, should be a topic for educational activities. Still, these educational actions must take place, in particular, on the occasion of the emergency hiring of health professionals to work in field hospitals, in view of the possible inexperience condition of the new professionals.

- Train/qualify the assistance and support team about HH through the adoption of a solid permanent education program ${ }^{(2-3,8)}$. If it is not possible to maintain a continuing education program, to meet the emergency demands of the pandemic, at least basic training on the importance of $\mathrm{HH}$ must be carried out to ensure patient safety ${ }^{(2)}$, using, for example, reminders in the workplace, which will be further discussed in the next component, to highlight the importance of $\mathrm{HH}$.

- Among the educational tools, training with the use of active strategies and online platform stands out. It is worth mentioning that knowledge about the transmission of the virus may still be incipient for certain categories of workers, requiring special attention. Optionally list applications and/or distance courses that address $\mathrm{HH}$ in the context of health ${ }^{(3)}$ and the pandemic of COVID-19, as educational strategies. Attention should be given to workers who do not have or do not master technological resources, and other tools should be considered, such as conversation circles and the use of audiovisual resources ${ }^{(2)}$.

\section{Component: "Reminder in the workplace”}

\section{DESCRIPTION}

Use of fundamental instruments to alert and remind health and support professionals, patients, family members about the importance of $\mathrm{HH}$ and the appropriate indications and techniques for this practice ${ }^{(2-3)}$. EXPECTED TIME

This component should be applied concurrently to educational activities, and continuously during the operation of the hospital.

\section{KEY ACTIONS FOR HM AND PATIENT SAFETY}

- Distribute visual alerts such as posters, plaques and posters at the entrance of temporary structures and in strategic locations, with information on the correct technique $\mathrm{e}^{(2-4)}$, and the importance of hands in transmitting the virus to the person and for environmental dissemination.

- Highlight the effectiveness of alcoholic solutions against the virus, its spread and survival in the environment, and the relevance of cleaning and disinfecting surfaces.

- Provide alert slogans adhered to the dispensers of alcoholic preparations for hands and devices ${ }^{(3)}$, with emphasis on their effectiveness against the virus.

- Distribute motivational phrases, in the corridors and computer screens, that encourage workers to join $\mathrm{HH}$ and understand their fundamental role in controlling the spread of the virus in the context of the pandemic. 
Chart 3 - Characteristics of the "Evaluation and feedback" component of the Multimodal Strategy and adaptations of the recommendations for the context of field hospitals

\begin{tabular}{l}
\hline Component: "Evaluation and feedback" \\
\hline DESCRIPTION \\
Essential component to identify areas that deserve great efforts and to \\
subsidize the updating of the action plan and increment of actions ${ }^{(2-3)}$, \\
with a view to reducing the cross-transmission of the virus. When con- \\
sidering the speed of information and guidelines related to the pan- \\
demic, evaluation and feedback are fundamental points for continuous \\
adjustments. \\
EXPECTED TIME \\
Considering the pandemic, and the need for updates, this component \\
should be operational within the first month of operation, weekly or \\
fortnightly, according to the context. \\
KEY ACTIONS FOR HM AND PATIENT SAFETY \\
- Investigating workers' confidence in the effectiveness of HH and al- \\
cohol gel against the virus is a fundamental strategy. \\
- Perform an audit during the practices of dressing and de-dressing \\
that are part of the daily care of patients with COVID-19, which is es- \\
sential for detecting errors with risk of self-contamination, as well as \\
for the correct HH in the initial and final stages direct care. \\
- Encourage team suggestions to improve this process; and develop- \\
ing new strategies. \\
- Establish and compare the results of care related to the practice of \\
HH, such as cases of horizontal transmission in the following areas: \\
patient-worker, worker-worker, patient-companion and worker- \\
companion. Provide feedback to workers, individually or collecti- \\
vely ${ }^{(4)}$. \\
- Evaluate and monitor infectious adverse events, especially the oc- \\
currence of cases and outbreaks of COVID-19 \\
sionals and in-hospital transmission to patients. \\
\hline
\end{tabular}

The Multimodal Strategy for field hospitals is applicable and valid to contribute substantially to the care practice in these care units. Although it is recognized that its application may vary according to the reality in which hospitals are inserted, it is believed that its use in the current pandemic scenario of COVID-19 is fundamental, in association with other measures, in combating the spread of the virus SARS-CoV-2. Having a guideline for the practice of $\mathrm{HH}$, strengthens and sustains the development of safe care practices, especially in coping with adverse situations imposed by the coronavirus on managers, researchers and professionals in the practice.

\section{FINAL CONSIDERATIONS}

The COVID-19 pandemic requires structural and organizational changes in order to limit the spread of the virus. In view of the promising results of the Multimodal Strategy in general hospitals, it is considered that its implementation, with adjustments for field hospitals, especially regarding the agility for the execution of the components, has the potential to prevent the spread of SARS-CoV-2 among patients and professionals, as well as to promote safe care practices. It is considered opportune to reflect on the applicability and propose adaptations in order to recognize the importance of the Multimodal Strategy and its adoption as a managerial tool, including in field hospitals and, especially, when considering the importance of hands as a vehicle and temporary SARS-CoV-2 vessel.

Health service managers and field hospital workers will be able to use the considerations presented here to break structural and behavioral limits regarding the practice of $\mathrm{HH}$, prioritizing the use of strategies as a tool to protect the patient and the team. The theme raises the direction of research to the scope of patient and worker safety, with a focus on prevention and mitigation of risks in the context of COVID-19 campaign hospitals.

\section{REFERENCES}

1. World Health Organization (WHO). Patient Safety [Internet]. 2019 [cited 2020 Apr 26]. Available from: https://www.who.int/news-room/ fact-sheets/detail/patient-safety

2. World Health Organization (WHO). A Guide to the Implementation of the WHO Multimodal Hand Hygiene Improvement Strategy [Internet]. Geneva:WHO; 2009 [cited 2020 Apr 29]. Available from: https://apps.who.int/iris/bitstream/handle/10665/70030/WHO_IER_PSP_2009.02_eng.pdf

3. Organização Mundial de Saúde. Higiene das Mãos na Assistência à Saúde Extra-hospitalar e Domiciliar e nas Instituições de Longa Permanência [Internet]. Brasília: Organização Pan-Americana da Saúde/ Agência Nacional de Vigilância Sanitária, 2014 [cited 2020 Jun 6]. Available from: https://edisciplinas.usp.br/pluginfile.php/361263/mod_resource/content/1/Manual_Higiene_Saude.pdf

4. Valim MD, Rocha ILS, Souza TPM, Cruz YA, Bezerra TB, Baggio E, et al. Efficacy of the multimodal strategy for Hand Hygiene compliance: an integrative review. Rev Bras Enferm. 2019;72(2):552-65. doi: 10.1590/0034-7167-2018-0584

5. World Health Organization (WHO). WHO Guidelines on Hand Hygiene in Health Care: a summary [Internet]. Geneva: WHO; 2009 [cited 2020 Jun 6]. Available from: https://www.who.int/gpsc/5may/tools/who_guidelines-handhygiene_summary.pdf

6. Ministério da Saúde (BR). Protocolo de manejo clínico da Covid-19 na Atenção Especializada [Internet]. Secretaria de Atenção Especializada à Saúde, Departamento de Atenção Hospitalar, Domiciliar e de Urgência. 1. ed. rev. - Brasília: Ministério da Saúde, 2020 [cited 2020 Apr 26 ]. Available from: https://portalarquivos.saude.gov.br/images/pdf/2020/April/14/Protocolo-de-Manejo-Cl--nico-para-o-Covid-19.pdf

7. Agência Nacional de Vigilância Sanitária (BR). Nota técnica no 08/2020. Orientações gerais para implantação das práticas de segurança do paciente em hospitais de campanha e nas demais estruturas provisórias para atendimento aos pacientes durante a pandemia de COVID-19 [Internet]. 2020 [cited 2020 Jun 6]. Available from: http://portal.anvisa.gov.br/documents/33852/271858/ Nota+t\%C3\%A9cnica+n+08-2020+GVIMS-GGTES-Anvisa-+Hospitais+de+Campanha/b3b1ee50-c92f-490e-a200-f89194ef5947

8. Agência Nacional de Vigilância Sanitária (BR). Nota técnica n 69/2020. Dispõe sobre as orientações gerais sobre Hospital de Campanha durante a pandemia internacional ocasionada pelo coronavírus SARS-CoV-2 [Internet]. 2020 [cited 2020 Apr 26]. Available from: http:// portal.anvisa.gov.br/documents/219201/4340788/NT+GGTES.pdf/b29aca21-15b1-4c51-91dd-dc12870c4e44 
9. World Health Organization. Recommendations to Member States to improve hand hygiene practices to help prevent the transmission of the COVID-19 virus. Interim guidance, 1 April 2020 [Internet]. Geneva: World Health Organization; 2020 [cited 2020 Mar 26]. Available from: https://www.who.int/publications-detail/ recommendations-to-member-states-to-improve-hand-hygiene-practices-to-help-prevent-the-transmission-of-the-covid-19-virus

10. Secretaria da Saúde do Estado do Paraná. Nota orientativa n²4/2020. Orientações para adequação da estrutura física em caráter temporário, na assistência de pacientes suspeitos ou confirmados para covid-19, em decorrência da emergência em saúde pública [Internet]. 2020 [cited 2020 Apr 30]. Available from: http://www.saude.pr.gov.br/arquivos/File/NO_24_ORIENTACOES_PARA_ADEQUACAO.pdf 